\title{
GENETIC ANALYSIS OF ARCHEOLOGICAL MAIZE FROM THE SITE OF SAN LORENZO (AZAPA, CHILE): A CONTRIBUTION TO THE PREHISPANIC MAIZE PROBLEM
}

\author{
ANÁLISIS GENÉTICO DE MAÍCES ARQUEOLÓGICOS \\ DEL SITIO SAN LORENZO (AZAPA, CHILE): UN APORTE A \\ LA PROBLEMÁTICA DEL MAÍZ PREHISPÁNICO
}

Wilson Huanca-Mamani ${ }^{1 *}$, Iván Muñoz $^{2}$, Delia Laime ${ }^{3}$ and Elizabeth Bastías ${ }^{1}$

\begin{abstract}
We report the first genetic analysis of archeological maize specimens from the site of San Lorenzo (1,500-700 BP) (Azapa valley, Arica, Chile). Ancient DNA was successfully isolated from 11 archeological maize grains. The Alcohol dehydrogenase 2 (Adh2) gene was analyzed because it has a highly variable region due to the presence of a microsatellite region around -28 to -8 , which consists of GA repeats that may be present in three types $\mathrm{GA}_{n}, \mathrm{GA}_{\mathrm{n}} \mathrm{TA}$ and $\mathrm{GA}_{1} \mathrm{AA}_{1} \mathrm{GA}_{\mathrm{n}}$, which is used as an informative region of the routes of initial dispersion of maize. Five $A d h 2$ alleles were obtained and the alignment of these sequences according to the variable region revealed the presence of the three types of GA repeated. Our results do not provide sufficient evidence to reject any maize spread model proposed. This is the first report focused on genetic analysis of maize associated with an archeological site in Chile.

Key words: Ancient DNA (aDNA), archeological maize, San Lorenzo, northern of Chile.
\end{abstract}

Este trabajo reporta el primer análisis genético de maíces arqueológicos del sitio San Lorenzo (1.500-700 BP) (Valle de Azapa, Arica, Chile). Se aisló de forma exitosa el ADN antiguo de 11 granos de maíces arqueológicos. Se analizó el gen de la Alcohol dehydrogenase 2 (Adh2), debido a que posee una región altamente variable por la presencia de un microsatélite entre el -28 y -8, la que consiste de un repetido de GA que puede estar presente en tres tipos; $G A_{n}$, $G A_{n} T A$ y $G A_{l} A A_{1} G A_{n}$, esta es utilizada como una región informativa de la ruta inicial de la dispersión del maíz. Se obtuvieron cinco alelos del gen Adh2 y el alineamiento de dichas secuencias, de acuerdo con la estructura de la región variable, reveló la presencia de los tres tipos de repetido de GA. Nuestros resultados no proveen suficientes evidencias para rechazar ningún modelo propuesto de dispersión del maíz. Este es el primer trabajo en Chile enfocado en el análisis genético de maíces procededentes de contextos arqueológicos.

Palabras claves: $A D N$ antiguo (ADNa), maíz arqueológico, San Lorenzo, norte de Chile.

Maize (Zea mays ssp. L. mays) is a principal domesticated crop of the Americas, originated from one or more varieties of teosinte. Although its origin in Mesoamerica has been established, its time of arrival and trajectory of spread through South America is still uncertain (Benz 2001; Matzuoka et al. 2002a; Lia et al. 2007; Staller and Thompson 2002). According to the archeological record maize was present in Central America around 6,250 years BP (Benz 2001; Piperno and Flannery 2001). However, its presence in South America has not been clearly established; direct archeological evidence indicates that its presence has been estimated between 4,500 years BP (Freitas et al. 2003; Pope et al. 2001).
In South America, the spread pattern of maize has been inferred from cytogenetic and genetic studies with several results (McClintock et al. 1981; Matzuoka et al. 2002a; Freitas et al. 2003; Lia et al. 2007; Babot 2011; Grimaldo 2011). Using cytogenetic studies based on the calculation of the frequencies and distribution of chromosome components, such as B-type chromosome, abnormal chromosome 10 and chromosome knobs, McClintock et al. (1981) suggested that maize was initially introduced into the central Andes and from there it spread to other highlands and lowlands in the continent, without being supplemented by other types of maize until new genotypes spread along the eastern Brazilian

1 Departamento de Producción Agrícola, Facultad de Ciencias Agronómicas, Universidad de Tarapacá, Arica, Chile.

* Corresponding author: whuanca@uta.cl; ebastias@uta.cl

2 Departamento de Antropología, Facultad de Ciencias Sociales y Jurídicas, Universidad de Tarapacá, Arica, Chile. imunoz@uta.cl

3 Departamento de Biología, Facultad de Ciencias, Universidad de Tarapacá, Arica, Chile. dlaime@uta.cl.

Recibido: mayo 2014. Aceptado: septiembre 2015.

http://dx.doi.org/10.4067/S0717-73562015005000050. Publicado en línea: 15-noviembre-2015. 
coast in recent times. Structural and phylogenetic analysis based on 193 and 752 maize accessions from eastern Canada to northern Chile using 99 and 96 microsatellites, performed by Matzuoka et al. (2002b) and Vigouroux et al. (2008) respectively, indicated a second model in which maize was spread into South America via Colombia and Venezuela and the Andes were populated from Colombia (Vigouroux et al. 2008).

Ancient DNA (aDNA) from maize recovered from archeological remains may play a role in our inference of its spreading. Genetic analysis of the short segment of Alcohol dehydrogenase 2 (Adh2) from primitive landraces and preserved maize remains from eastern Brazil, Peru and northern Chile shows the presence of three allele groups differentially distributed within South America, supporting a third model with two separate expansions of maize spreading. One expansion came from highlands Central America into the Andean region and a second expansion along lowlands of the northeast coast of the continent (Freitas et al. 2003).

On the Pacific side the maize cultivation reached a large part of Chile, morphological analysis has been performed in some of these archeological samples; unfortunately, maize from Cabuza, a burial site on the northern coast of Chile, has only been analyzed genetically (Goloubinoff et al. 1993). In Chile the earliest evidence of maize comes from Tiliviche Site 1b, located in the Tiviliche ravine 35 $\mathrm{km}$ from Pacific coast (Núñez 1986). According to Núñez and Moragas (1977), stratigraphic evidence initially suggested that leaves and cobs of maize were found dated around 7,850 BP and 6,060 BP (uncalibrated), corresponding to the Piricinco coroico complex, linked to tropical lands of eastern Bolivia (Núñez and Moragas 1977). However this kind of indirect dating is becoming a significant problem because the association between the material used for dating, such as wood charcoal, and the maize macro remains are not always secure (Long et al. 1989). Performing direct dating through accelerated mass spectrometry (AMS) approach on maize macro remains from early deposits of the Tiliviche site, Unit-2, showed that these were dated around 1,000 BP (Rivera 2006).

Currently in Chile 23 maize races have been identified, most of them grow in the northern regions such as Harinoso Tarapaqueño, Limeño, Chulpi, Polulo, Capio chileno grande, Capio chileno chico, Chutucuno, Morocho Amarillo, Negrito chileno,
Marcane and Curagua among others (Paratori et al. 1990).

Since maize samples recovered from archeological sites are not always well-enough preserved for a morphological or racial identification, ancient DNA is an important tool for understanding the history of the domestication and spreading of maize cultivation in South America (Lia 2007; Schlumbaum et al. 2008).

In northern Chile there is an enormous variety of maize landraces and several archeological sites with maize samples directly dated up to 2,210 years BP (Blake 2006), however there is only one genetic study on ancient maize (Goloubinoff et al. 1993).

In this study we analyzed archeological maize seeds associated with funerary remains from the site of San Lorenzo (1,500-700 BP (Muñoz 2004)) and local modern maize landraces were analyzed for the short and highly variable region (microsatellite) present in the Adh 2 gene. The site of San Lorenzo, in the Azapa valley (Arica, Chile), is probably first administrative site of all northern Chile (Muñoz 2004; Muñoz and Focacci 1985). San Lorenzo maize samples could contribute new evidence to unravel which maize expansion model into South America occurred.

\section{Methods}

\section{Archeological and modern maize seed description}

Collection sites, ID, age, type of remains and context of the individuals examined in archeological and modern maize landraces are described in Table 1. The location of archeological site is shown in Figure 1. Archeological samples were dated between 1,200 $-1,000$ BP (Muñoz 2004). The samples correspond to 20 maize grains found in funerary remains in San Lorenzo site 11 (SL) located in the Azapa valley (Arica, Chile). These grains show differences in seed coat colors, suggesting that they come from different types of maize (Figure 2). The modern samples correspond to grains of local maize landrace from the Lluta, Socoroma and Camiña valleys (Chile) and Pachía valley (Peru) (Figures 1 and 2).

\section{DNA analysis}

The ancient DNA extraction and PCR setup were performed in a laminar flow hood (ESCO laminar 
Table 1. Maize samples used in this work.

Muestras de maíz utilizados en este trabajo.

\begin{tabular}{llcccc}
\hline Collection site & ID $^{\mathrm{a}}$ & Altitude (m.a.s.l.) & Age (years BP) & Type of remains & Context $^{\mathrm{b}}$ \\
\hline $\begin{array}{l}\text { Archaeologycal maize samples } \\
\text { San Lorenzo, Valle de Azapa, Arica, Chile }\end{array}$ & SL & 400 & $1,200-1,000$ & grain & F \\
$\begin{array}{l}\text { Modern maize samples } \\
\text { Valle de Lluta, Región de Arica y Parinacota, Chile }\end{array}$ & Ll & $<250$ & - & - & - \\
Valle de Socoroma, Región de Arica y Parinacota, Chile & Soc & 3060 & - & - & - \\
Valle de Camiña, Región de Tarapacá, Chile & Cam & 4124 & - & - & - \\
Valle de Pachía, Departamento de Tacna, Tacna, Perú. & Pa & $<1500$ & - & - & - \\
\hline
\end{tabular}

a SL, San Lorenzo sitio 11; Ll, lluteño maize; Soc, Socoroma maize: Cam, Camiña maize; Pa, Pachía maize.

b Context from which samples were recovered: F, funerary.
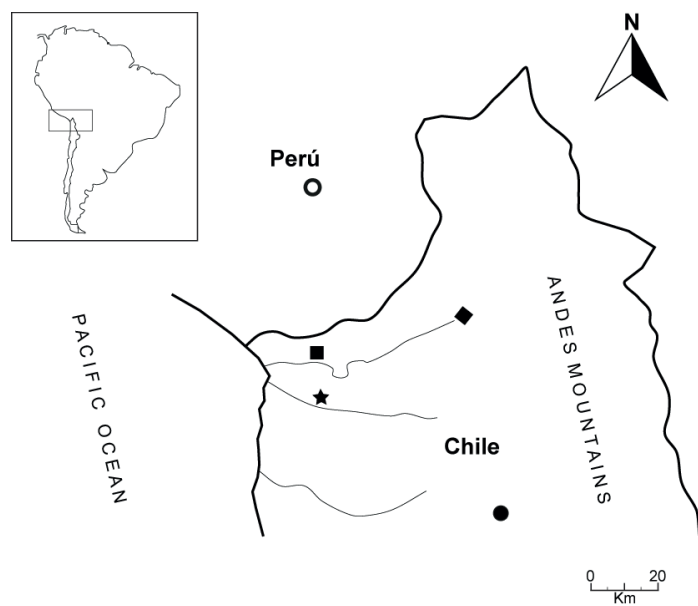

Figure 1. Location of the archaeological site and the valleys where modern maize landraces were collected. $\star$ San Lorenzo site-11; Lluta valley; $\bullet$ Socoroma valley; $\bullet$ Camiña valley; O Pachía valley.

Ubicación del sitio arqueológico y de los valles donde las razas de maíces modernos fueron colectados. $\star$ San Lorenzo sitio-11;

- Valle de Lluta; Valle de Socoroma; - Valle de Camiña; - Valle de Pachía.

flow) in a laboratory dedicated to this purpose. All equipment was first wiped with bleach $(10 \%)$ and then exposed to UV light for at least $1 \mathrm{~h}$ inside the laminar flow hood. Stringent measures were taken to prevent contamination with modern maize DNA. To remove external contaminant sources of DNA, archeological seeds were washed in $10 \%$ bleach for 5 minutes, rinsed with sterile and deionized $\mathrm{H}_{2} \mathrm{O}$ and dried at room temperature under laminar flow hood. The seed coat was removed using a scalpel; following this each seed was powdered in a mortar and placed in an Eppendorf tube. Nucleic acids from archeological grains were extracted using the Qiagen DNA extraction kit and Insect DNA kit
A

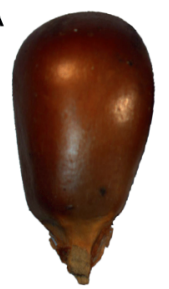

D

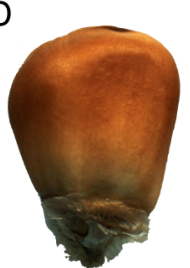

G

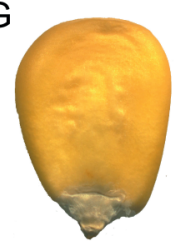

B

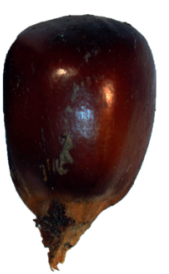

E

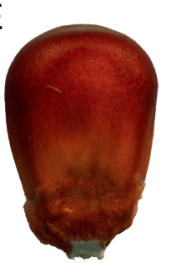

$\mathrm{H}$

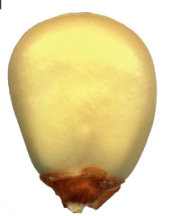

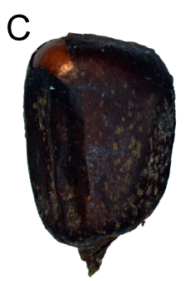

$\mathrm{F}$

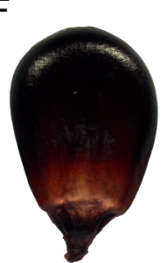

I

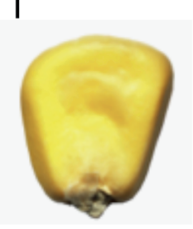

Figure 2. Archaeological and modern maize analyzed. A-C, archeological grains and D-I, modern grains. A, SL-1; B SL-2; C, SL-3; D, Socoroma-15; E, Socoroma-16; F, Socoroma-10; G, lluteño; H, Camiña; I, Pachía.

Maíces arqueológicos y modernos analizados. A-C, granos arqueológicos D-I, granos modernos. A, SL-1; B SL-2; C, SL-3; D, Socoroma-15; E, Socoroma-16; F, Socoroma-10; G, lluteño; H, Camiña; I, Pachía.

(Omega-BioTek), according to the manufacturers' instructions with minor modifications (unpublished results). Elution of DNA was repeated twice with $50 \mu \mathrm{l}$ of $\mathrm{ddH}_{2} \mathrm{O}$ each time.

Nucleic acid extraction from modern maize landraces were performed using the 
cetyltrimethylammonium bromide (CTAB) method as described by Doyle and Doyle (1990). The modern DNA was extracted in a separate laboratory.

\section{PCR conditions}

The PCR setup was performed in the same laminar flow hood used for the aDNA extraction, using dedicated pipettes and aerosol barrier tips. Equipment was wiped with bleach and then the equipment and reagent tubes were exposed to UV light for at least $1 \mathrm{~h}$ before setting up the mix.

PCR reactions were performed in a final volume of $20 \mu \mathrm{l}$. Each reaction contained $3 \mu \mathrm{l}$ of DNA extract, 10 pmoles of each Adh2 primer (Table 2), $2.5 \mathrm{mM}$ of each dNTP, $2 \mathrm{mM} \mathrm{MgCl}_{2}$, $1 \mathrm{X}$ PCR buffer $\left(\left(\mathrm{NH}_{4}\right)_{2} \mathrm{SO}_{4}\right), 5$ units of Taq DNA polymerase (Fermentas) and sterile double distilled water. Cycling conditions were: $10 \mathrm{~min}$ at $94{ }^{\circ} \mathrm{C}$; 40 cycles of $1 \mathrm{~min}$ at $94^{\circ} \mathrm{C} ; 1 \mathrm{~min}$ at $48^{\circ} \mathrm{C} ; 1 \mathrm{~min}$ at $72{ }^{\circ} \mathrm{C}$ and a final elongation step of $10 \mathrm{~min}$ at $72{ }^{\circ} \mathrm{C}$. PCR reactions incorporated one PCR blank reaction for each primer. Five $\mu \mathrm{l}$ of each PCR product was visualized on $2 \%$ agarose gels stained with gel-red (Biotium). Reactions containing fragments of the expected size were directly sequenced by a commercial facility (Macrogen, South Korea); samples SL-2.2 and SL-3.2 were re-amplified using 1 $\mu 1$ of the PCR reaction under the following conditions: $10 \mathrm{~min}$ at $94{ }^{\circ} \mathrm{C} ; 35$ cycles of $30 \mathrm{sec}$ at $94{ }^{\circ} \mathrm{C} ; 40$ sec at $50^{\circ} \mathrm{C} ; 40 \mathrm{sec}$ at $72{ }^{\circ} \mathrm{C}$ and final elongation step of $2 \mathrm{~min}$ at $72^{\circ} \mathrm{C}$. Modern maize samples were amplified using $200 \mathrm{ng}$ of DNA and Adh2UM-long primers under the following conditions: $5 \mathrm{~min}$ at $94{ }^{\circ} \mathrm{C}$; 35 cycles of $30 \mathrm{sec}$ at $94{ }^{\circ} \mathrm{C} ; 30 \mathrm{sec}$ at 55 ${ }^{\circ} \mathrm{C} ; 30 \mathrm{sec}$ at $72{ }^{\circ} \mathrm{C}$ and a final elongation step of 2 min at $72{ }^{\circ} \mathrm{C}$. Reactions containing fragments of the expected size were directly sequenced by a commercial facility (Macrogen, South Korea).
All sequences were edited and then aligned by the CLUSTAL $\mathrm{W}$ method implemented in MEGA 6 (Tamura et al. 2013).

\section{Results}

Twenty archeological maize grains from funerary remains in San Lorenzo site were used for ancient DNA extraction, Figure 2. Two DNA extraction kits were used to isolate aDNA and better results were obtained with the Bio-Tec protocol with minor modifications (unpublished results). Ancient DNA was successfully amplified by PCR in 11 grains, obtaining amplicons of the expected size; these samples were selected for direct sequencing. Good sequences were obtained from 5 . In the remaining 6 samples it was not possible to reconstruct the $A d h 2$ fragment. DNA extracted had a low molecular weight under $150 \mathrm{bp}$, because PCR amplification fragments were obtained using either Adh2UM or Adh2-S2 primers, which amplify fragments of 108 and 143 bp, respectively; we did not detect PCR products using the Adh2UM-long primer, which amplifies a fragment of $220 \mathrm{bp}$. No PCR products were obtained in any negative control (data not shown).

Six modern maize landraces (Figure 2) cultivated in the Lluta, Camiña and Socoroma valleys (Chile) and in the Pachía valley (Peru), located around the San Lorenzo archaeological site, were analyzed by PCR using Adh2-S2 primers and a fragment of 143 bp was sequenced for each sample.

Short Adh2 fragments from the archeological samples and modern landraces were aligned. A feature of the sequence amplified is the presence of a microsatellite region around -28 to -8 , which consists of GA repeats that may be present in three types $\mathrm{GA}_{\mathrm{n}}$, $\mathrm{GA}_{\mathrm{n}} \mathrm{TA}$ and $\mathrm{GA}_{1} \mathrm{AA}_{1} \mathrm{GA}_{\mathrm{n}}$ (Goloubinoff et al. 1993; Freitas et al. 2003). All three types of repeats were found in the samples examined (Figure 3).

Table 2. Primers sequences and predicted product lenghts.

Secuencia de los iniciadores y longitud de los productos esperados.

\begin{tabular}{|c|c|c|c|}
\hline Name & Sequence & Annealing $\left({ }^{\circ} \mathrm{C}\right)$ & Product lenght (bp) \\
\hline Adh2-UM ${ }^{1}$ & $\begin{array}{l}\text { TCGTGTTCTTGGAGTGGTCCATCG } \\
\text { ACGCACGCACCTCTGCACTT }\end{array}$ & 48 & 103 \\
\hline Adh2-S $2^{2}$ & $\begin{array}{l}\text { GCAAAAGGATTCCATTCTCGTG } \\
\text { CACGAAAGGTGGAGGTAGAAG }\end{array}$ & 48 & 143 \\
\hline Adh2-UM-long ${ }^{1}$ & $\begin{array}{l}\text { TGCGAAGAAGCAGTAGCAAA } \\
\text { GCAGAGGGATCCAAGAACAA }\end{array}$ & 55 & 220 \\
\hline
\end{tabular}

\footnotetext{
From Grimaldo (2011).
}

2 This research. 


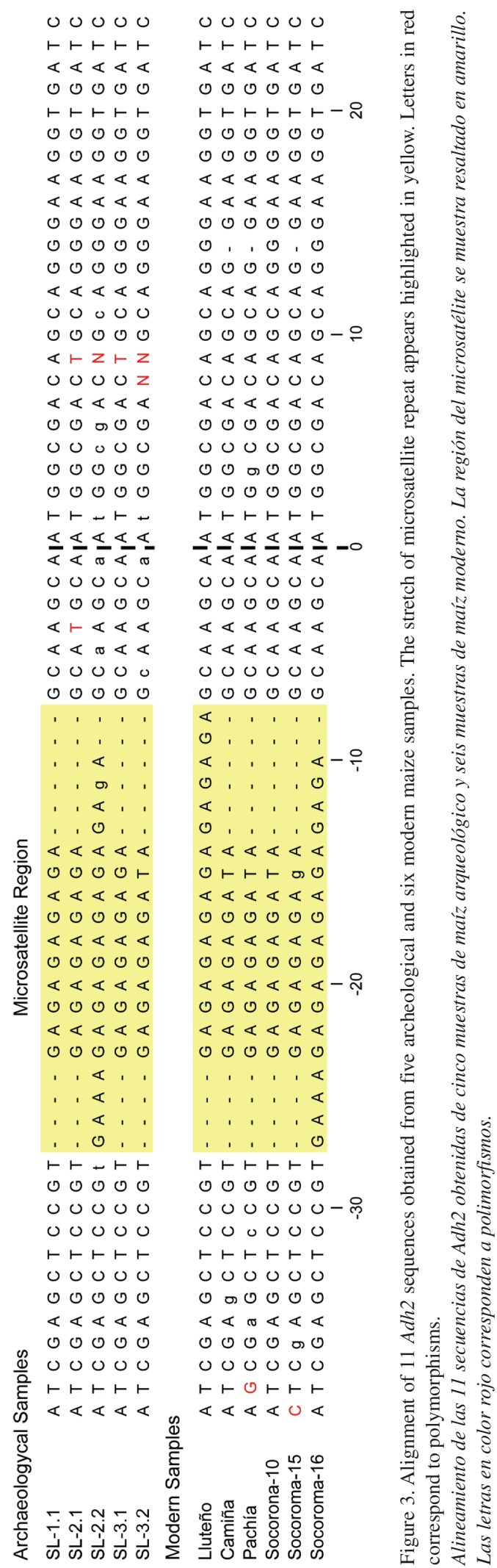


Three archeological maize grains SL-1.1, SL-2.1 and SL-3.1 presented the dinucleotide GA repeat type $\mathrm{GA}_{5}$; one grain SL-2.2 and one grain SL-3.2 showed the dinucleotide GA repeats type $\mathrm{GA}_{1} \mathrm{AA}_{1} \mathrm{GA}_{7}$ and $\mathrm{GA}_{4} \mathrm{TA}_{1}$, respectively (Figure 3). Additionally, archeological sequences reveled sequence variations at a total of three single nucleotide positions and another three positions where it was not possible to identify the correct nucleotide (Figure 3).

The modern maize sample from Camiña Valley presented the $\mathrm{GA}_{4} \mathrm{TA}_{1}$ type dinucleotide repeat; maize from Socoroma valley had the $\mathrm{GA}_{5}, \mathrm{GA}_{4} \mathrm{TA}_{1}$ and $\mathrm{GA}_{1} \mathrm{AA}_{1} \mathrm{GA}_{7}$ types; the maize from Lluta valley presented the $\mathrm{GA}_{8}$ type and maize from Pachía valley showed the $\mathrm{GA}_{4} \mathrm{TA}_{1}$ type (Figure 3 ).

\section{Discussion}

According to Muñoz and Focacci (1985) consider to settlement of San Lorenzo as a large village who would have been an administrative center in the lower area of Azapa Valley. This hypothesis is due to San Lorenzo is placed in a strategic location in the valley, its architectural features, its square, territorial expansion, large number of venues, perimeter walled, cemeteries and road networks among other. These make it a nuclear space of multiple economic and social relations. San Lorenzo agricultural development peaked between 1,2101,020 BP (Muñoz 2004).

Apart from being an administrative center, San Lorenzo was also a passage where various goods were transported, including maize, from the Peruvian coast (Núñez 1976). Good water quality of the Azapa valley may have been the principal interest for initiating maize cultivation, for example, the Tiwanaku culture used these water resources for fruit farming development, which did not occur in other valleys located in the area that have salty water.

Currently evidence suggest that maize is grown in the coastal valleys of the Pacific, during the Formative period, around 3,000 B P. According to Rivera (1980) during this period is the beginnings of peasant farming process and the introduction of Capio maize race. During 1,400 to $1,200 \mathrm{BP}$, the maize would have constituted the basis of the late village sedentary populations and addition, a probable center of diversification in meridional Andean area, from which Northern
Chile was part (Rivera 1980). These events may have initiated the interest of San Lorenzo's farmers to cultivate maize in this semitropical valley, which gave rise economic development and the appearance of an administrative center. According to maize cobs analysis, these were identified as Piricinco/Coroico race (Muñoz 2004), a floury maize race widely distributed in South America (Grobman 2013).

\section{Ancient DNA}

The recovery of DNA from archeological maize grains from funerary remains demonstrated good genomic DNA preservation and is quite encouraging for future research. The results also indicate that it is highly unlikely that any of the data derived from contamination from external modern maize DNA. No PCR control showed any cross contamination. Independent replication of aDNA analyses is suggested to ensure the quality of data and conclusions (Cooper and Poinar 2000; Pääbo et al. 2004), however we subscribe to the view of Gilbert et al. (2005), in which aDNA research should be validated using a cognitive approach. As the PCR controls did not show evidence of any contamination, including control re-amplification reactions, and the samples clearly yielded maize genomic DNA sequences, it is very unlikely that our results derive from contamination, thus they do not require independent validation. It was not possible to obtain amplification products greater than $145 \mathrm{bp}$ in archeological samples, which agrees with previous reports, because DNA in archeological samples is generally degraded to small sizes (Jaenicke-Després et al. 2003), besides the amplification of alleles by amplicon size circumvents problems caused by diagenetics modifications when nucleotides polymorphisms are typed in aDNA (Lia et al. 2007; Pääbo 1989). The sizes of Adh2 fragments amplified were consistent with the sizes previously reported (Freitas et al. 2003; Grimaldo 2011).

Three archeological samples showed the presence of the simple dinucleotide $\mathrm{GA}$ repeat type $\mathrm{GA}_{5}$, one sample presented the type $\mathrm{GA}_{1} \mathrm{AA}_{1} \mathrm{GA}_{7}$ and one sample had the type $\mathrm{GA}_{4} \mathrm{TA}$ of this microsatellite. There was not relation between the seed coat color of the maize grain associated to a specific microsatellite. The three types of this GA repeat were also found in the six modern land races analyzed. Maize from the 
Lluta and Socoroma valleys had the type $\mathrm{GA}_{\mathrm{n}}(\mathrm{n}=5$ 8). A second maize sample from Socoroma valley showed the type $\mathrm{GA}_{1} \mathrm{AA}_{1} \mathrm{GA}_{7}$ and maize samples from Socoroma and Pachía valleys presented the type $\mathrm{GA}_{4} \mathrm{TA}$ (Figure 3). In relation to $A d h 2$ sequences, the microsatellite analysis, suggests lightly a linking between archeological and modern samples from the highlands. Analysis of archeological samples from other sites around Azapa valley will be necessary for evaluate this linking.

Modern maize samples show differences between lowland and highland maize. The Lluta valley is a coastal valley, while the Pachía valley is over 1500 m elevation; the Socoroma and Camiña valleys are in the Andes region at around 2,000 m. Lluteño maize has the longer dinucleotide GA repeat type $\mathrm{GA}_{8}$, while Andean maize has the three types $\mathrm{GA}_{5}, \mathrm{GA}_{1} \mathrm{AA}_{1} \mathrm{GA}_{7}$ and $\mathrm{GA}_{4} \mathrm{TA}_{1}$. The type $\mathrm{GA}_{8}$ is associated mainly with samples from near the coast (Goloubinoff 1993; Freitas et al. 2003; Grimaldo 2011). Lluteño maize presents the allele $\mathrm{GA}_{8}$ type is similar to archeological maize from coastal Peru (Goloubinoff 1993; Grimaldo 2011).

\section{Adh2 and maize cultivation expansion into South America}

The three AG repeat types present in Adh2 gene described above have different distributions within South America and have been found in modern maize cultivars from North America. In addition, the presence of the $\mathrm{GA}_{\mathrm{n}}$ and $\mathrm{GA}_{\mathrm{n}} \mathrm{TA}$ types in the teosinte varieties $Z$. m. mexicana and $Z$. $m$. parviglumis suggests that the presence of these three repeat types in South America is due to introduction of these genotype to the highland from Central America rather than diversification of an ancestral genotype within South America (Freitas et al. 2003; Goloubinoff et al. 1993). A different view was proposed by Freitas (2003), who suggested that two introduction events of maize into South America occurred, one from highland of Central America into the Andes region and a second event along the lowlands from Central America into lowlands of the northeast coast of South America (Freitas et al. 2003). This model was supported by Vigouroux et al. (2008), through a more comprehensive study of microsatellites in modern landraces.

The model proposed by Freitas et al. (2003) is supported by the unequal Adh2 allele distribution in South America. The $\mathrm{GA}_{\mathrm{n}}$ allele was identified mainly in western sites, while the $\mathrm{GA}_{\mathrm{n}} \mathrm{TA}$ and $\mathrm{GA}_{1} \mathrm{AA}_{1} \mathrm{GAn}$ alleles were found along eastern area of South America. Nonetheless, in a subsequent study analyzing a larger number of archaeological sites in western areas Grimaldo (2011) reported a wide distribution of all three AG repeat types, however the type $\mathrm{GA}_{\mathrm{n}}$ was associated mainly with samples from the western area and the types $\mathrm{GA}_{\mathrm{n}} \mathrm{TA}$ and $\mathrm{GA}_{1} \mathrm{AA}_{1} \mathrm{GA}_{\mathrm{n}}$ were found along eastern area of South America. Currently, in modern maize these alleles are widely distributed in South America, except the type $\mathrm{GA}_{\mathrm{n}}$ which is present at low frequency at the eastern side of South America (Freitas et al. 2003 and Grimaldo 2011).

In our study, Adh2 gene analysis is still not enough to assign clearly the ancient samples to a modern variety probably the small ancient sample size is an inevitable constraint of this kind of studies (Lia et al. 2007) and because there is not genetic analysis available to ensure these modern landraces have not been affected by movement of commercial germplasm or interbreeding between landraces during post-Columbian period. However, our results are pertinent and useful to establish the implications for the maize cultivation spread into South America. In the archeological maize samples from the site of San Lorenzo we found all 3 AG repeat types described for Adh2 gene. Our results support and complement the model proposed by McClintock (1981), in which maize was initially introduced in the central Andes and then spread extensively throughout the highland and lowland areas of South America. Also, our results are concordant with two maize expansion model proposed by Freitas et al. (2003), which there was mixing of genotype between east and west of South America, the meeting ground of theses two expansions, between the northern Chile, where the samples under study come from and Paraguay. This meeting ground is supported by the results of Lia et al. (2007) for Andean origin of some Argentinean races who, analyzing three microsatellite loci, found that archaeological samples from Northwestern Argentina possessed alleles specific to Andean races. Our results do not provide sufficient evidence to overturn any maize spread model proposed.

Archeological evidence suggests that in Chile maize may have appeared between 7,850 and 3,000 $\mathrm{BP}$, but agriculture did not become established until 1,600 BP (Núñez and Moragas 1977; Pope et al. 
2001; Freitas et al. 2003). The discrepancies in the dating to establish the presence of maize on Chile is due to the first measurements were performed by indirect stratigraphic approaches (Núñez 1986; Núñez and Moragas 1977; Schiappacasse and Niemeyer 1984). Indirect dating involves a significant problem because the association between the material used for dating and the maize macro remains are not always secure (Long et al. 1989). A new chronological history should be reconfirmed with new radiometric dating obtained directly from maize and evaluate the stratigraphy where these samples were found.

This is the first report focused on genetic analysis of maize associated with an archeological site in
Chile. Due to the large number of archeological sites in northern Chile where maize remains may be found (Rivera 2006), these types of studies are necessary for understanding the ancestral route of maize cultivation in Chile.

Acknowledgments: We are especially grateful to Claudia Grimaldo Giraldo for critical comments on the manuscript. This research received support from Fondecyt 11100492, Fondecyt 1130249, UTAMayor 4710-13 and Convenio de Desempeño en Educación Superior Regional UTA-1401. Finally, we would like to thank the anonymous reviewers for their relevants comments which were very helpful and enhanced this work.

\section{References Cited}

Babot, M. del P. 2011. Cazadores-recolectores de los Andes Centro-Sur y procesamiento vegetal. Una discusión desde la Puna Meridional Argentina (ca. 7000-3200 años a.p.). Chungara Revista de Antropología Chilena 43:413-432.

Benz, B.F. 2001. Archaeological evidence of teosinte domestication from Guila' Naquitz, Oaxaca. Proceedings of the National Academy of Sciences of the United States of America 98:2104-2106.

Blake, M. 2006. Dating the initial spread of Zea mays. In Histories of Maize: Multidisciplinary Approaches to the Prehistory, Biogeography, Domestication, and Evolution of Maize, edited by J.E. Staller, R.H. Tykot and B.F. Benz, pp. 55-78. Academic Press, Amsterdam.

Cooper, A. and H.N. Poinar 2000. Ancient DNA: Do it right or not at all. Science 289:1139.

Doyle, J.J. and J.L. Doyle 1900. Isolation of plant DNA from fresh tissue. Focus 12:13-15.

Freitas, F., G. Bendela, R. Allaby and T.A. Brown 2003. DNA from primitive maize landraces and archaeological remains: implications for the domestication of maize and its expansion into South America. Journal of Archaeological Science 30:901-908.

Gilbert, T., H.J. Bandelt, M. Hofreiter and I. Barnes 2005. Assessing ancient DNA studies. Trends in Ecology and Evolution 20:541-544.

Grimaldo, C. 2011. Investigating the Evolutionary History of Maize in South America. PhD Thesis in Philosophy, Faculty of Life Sciences, University of Manchester, Manchester.

Grobman, A. 2013. Maize: Origin, Domestication, and Its Role in the Development of Culture. Cambridge University Press, New York.

Goloubinoff, P., S. Pääbo and A.C. Wilson 1993. Evolution of maize inferred from sequence diversity of an adh2 gene segment from archaeological specimens. Proceedings of the National Academy of Sciences of the United States of America 90:1997-2001.
Jaenicke-Després, V., E.S. Buckler, B.D. Smith BD, M.T.P Gilbert, A. Cooper, J. Doebley and S. Pääbo 2003. Early allelic selection in maize as revealed by ancient DNA. Science 302:1206-1208.

Lia, V.V., V.A. Confalonieri, N. Ratto, J.A. Cámara-Hernandez, A.M. Miante-Alzogaray, L. Poggio and T.A. Brown 2007. Microsatellite typing of ancient maize: Insights into the history of agriculture in southern South America. Proceedings of the Royal Society B 274:545-554.

Long, A., B.F. Benz, D.J. Donahue, A.J.T. Jull and L.J. Toolin 1989. First Direct AMS Dates on Early Maize From Tehuacan, México. Radiocarbon 31:1035-1040.

Matsuoka, Y., S.E. Mitchell, S. Kresovich, M.M. Goodman and J.F. Doebley 2002a. Microsatellites in Zea-variability, patterns of mutations, and use for evolutionary studies. Theoretical and Applied Genetics 104:436-450.

Matsuoka, Y, Y. Vigouroux, M.M. Goodman, J. Sanchez, G.E. Buckler and J.F. Doebley 2002b. A single domestication for maize shown by multilocus microsatellite genotyping. Proceedings of the National Academy of Sciences of the United States of America 99:6080-6084.

McClintock, B., T.A. Kato and A. Blumenschein 1981. Chromosome constitution of the races of maize. Its significance in the interpretation of relationships between races and varieties in the Americas. Colegio de Postgraduados, Chapingo.

Muñoz, I. 2004. Estrategias de Organización Prehispánicas en Azapa: El Impacto de la Agricultura en un Valle del Desierto Costero del Pacífico. Ediciones Universidad de Tarapacá, Arica.

Muñoz, I. and G. Focacci 1985. San Lorenzo: Testimonio de una comunidad de agricultores y pescadores en el valle de Azapa. Chungara 15:7-30.

Núñez, L. 1976. Geoglifos y Tráfico de Caravanas en el Desierto Chileno. Homenaje al Dr. R.P. Gustavo Le Paige, edited by L. Núñez, pp. 147-201. Universidad del Norte, Antofagasta. 
Nuñez, L. 1986. Evidencias arcaicas de maíces y cuyes en Tiliviche: hacia el semisedentarismo en el litoral fértil y quebradas del norte de Chile. Chungara 16-17:25-47.

Núñez, L. and C. Moragas 1977. Ocupación Arcaica Temprana en Tiliviche, norte de Chile, I Región. Boletín Museo Regional de La Serena 16:53-76.

Pääbo, S. 1989. Ancient DNA: extraction, characterization, molecular cloning, and enzymatic amplification. Proceedings of the National Academy of Sciences of the United States of America 86:1939-1943.

Pääbo, S., H. Poinar , D. Serre, V. Jaenicke-Despres, J. Hebler, N. Rohland, M. Kuch, J. Krause, L. Vigilant and M. Hofreiter 2004. Genetic analyses from ancient DNA. Annual Reviews Genetics 38:645-79.

Paratori, O., R. Sbárbaro and C. Villegas 1990. Catálogo de recursos genéticos de maíz de Chile. Instituto de Investigaciones Agropecuarias. Boletín Técnico 165.

Piperno, D.R. and K.V. Flannery 2001. The earliest archaeological maize (Zea mays L.) from highland Mexico: new accelerator mass spectrometry dates and their implications. Proceedings of the National Academy of Sciences of the United States of America 98:2101-2103.

Pope, K.O., M.E. Pohl, J.G. Jones, D.L. Lentz, C. von Nagy, F.J. Vega and I.R. Quitmyer 2001. Origin and environmental setting of ancient agriculture in the lowlands of Mesoamerica. Science 292:1370-1373.
Rivera, M. 1980. La agriculturación del maíz en el norte de Chile: Actualización de problemas y metodología de investigación. Temas Antropológicos del Norte de Chile. Estudios Arqueológicos Número especial 105-129.

Rivera, M. 2006. Prehistoric maize from northern Chile An evaluation of the evidence. In Histories of Maize: Multidisciplinary Approaches to the Prehistory, Biogeography, Domestication, and Evolution of Maize, edited by J.E. Staller, R.H. Tykot and B.F. Benz, pp. 403-413. Academic Press, Amsterdam.

Staller, J.E. and R.G. Thompson 2002. A multidisciplinary approach to understanding the initial introduction of maize into coastal Ecuador. Journal of Archaeological Science 29:33-50.

Schlumbaum, A., M. Tensen and V. Jaenicke-Deprés 2008. Vegetation History and Archaeobotany 17:233-244.

Schiappacasse, V. and H. Niemeyer 1984. Descripción y análisis interpretativo de un sitio arcaico temprano en la quebrada de Camarones. Publicación Ocasional 41. Ediciones del Museo Nacional de Historia Natural, Santiago.

Tamura, K., G. Stecher, D. Peterson, A. Filipski and S. Kumar 2013. MEGA6: Molecular Evolutionary Genetics Analysis version 6.0. Molecular Biology and Evolution 30:2725-2729.

Vigouroux, Y., J.C. Glaubitz, Y. Matsuoka, M.M. Goodman, G.J. Sánchez and J. Doebley 2008. Population structure and genetic diversity of New World maize races assessed by DNA microsatellites. American Journal of Botany 95:1240-1253. 
